\title{
Faktor-Faktor yang Berpengaruh terhadap Kinerja Guru Taman Kanak-Kanak
}

\author{
Warih Anggi Pratiwi ${ }^{1}{ }^{凶}$, Iis Prasetyo ${ }^{2}$, Monita Nur Shabrina ${ }^{3}$ \\ Pendidikan Anak Usia Dini, Universitas Negeri Yogyakarta ${ }^{(1,3)}$ \\ Pendidikan Luar Sekolah, Universitas Negeri Yogyakarta(2) \\ DOI: $\underline{10.31004 / \text { obsesi.v5i2.970 }}$
}

\begin{abstract}
Abstrak
Penelitian ini bertujuan untuk mengetahui faktor-faktor yang mempengaruhi kinerja guru di Taman Kanak-kanak se-Kabupaten Sukoharjo Jawa Tengah. Penelitian ini menggunakan penelitian kuantitatif. Teknik pengumpulan data menggunakan kuesioner/angket. Teknik analisis data dalam penelitian ini menggunakan analisis faktor atau disebut CFA (Confirmatory Factor Analysis). Hasil penelitian menunjukkan bahwa faktor individu (kompetensi guru) yang terdiri dari kompetensi pedagogik, kompetensi kepribadian, kompetensi profesional dan kompetensi sosial berpengaruh terhadap kinerja guru, hal ini dibuktikan dengan nilai Eigenvalues sebesar 2,506. Hasil penelitian menunjukkan bahwa faktor psikologis yaitu motivasi guru berpengaruh terhadap kinerja guru, hal ini dibuktikan dengan nilai Eigenvalues sebesar 1,462. Hasil penelitian menunjukkan bahwa faktor organisasi yaitu disiplin guru berpengaruh terhadap kinerja guru, hal ini dibuktikan dengan nilai Eigenvalues sebesar 1,005.
\end{abstract}

Kata Kunci: faktor penentu; kinerja guru; taman kanak-kanak

\begin{abstract}
This research is aimed to find out some factors that actually give much contribution to the kindergarten teachers in Sukoharjo regency in terms of their working performance. This is a quantitative research which employed questionaire method as data collection. The data were analyzed using Confirmatory Factor Analysis (CFA). The results showed that individual factors (teacher competence) consisting of pedagogic competence, professional competence and social competence had an effect on teacher performance, this was evidenced by the Eigenvalues value of 2.506. The results showed that psychological factors, namely teacher motivation, had an effect on teacher performance, this was evidenced by the Eigenvalues value of 1.462. The results showed that the organizational factors that influence teacher performance, this is evidenced by the Eigenvalues value of 1.005 .
\end{abstract}

Keywords: affecting factors; performance teachers; kindergarten

Copyright (c) 2021 Warih Anggi Pratiwi, Iis Prasetyo, Monita Nur Shabrina

$\square$ Corresponding author:

Email Address : anggip444@@gmail.com (Yogyakarta, Indonesia)

Received 15 December 2020, Accepted 31 December 2020, Published 6 Januari 2021 


\section{PENDAHULUAN}

Pendidikan dipandang sebagai salah satu kebutuhan utama manusia dalam pembangunan materiil dan spiritual dalam menghadapi era kemajuan. Peran guru menjadi salah satu sumber daya yang menentukan keberhasilan pendidikan terutama dalam kegiatan belajar dan mengajar di sekolah (Supriyono, 2017). Guru merupakan suatu prioritas pertama dalam mewujudkan keberhasilannya suatu pendidikan, oleh karena itu melihat kemajuan zaman yang serba cepat dan canggih perlunya seorang pendidik meningkatkan kualitasnya sehingga dapat menjajarkan pengetahuan dengan tuntutan zaman sekarang ini, setiap pendidik profesional diharapkan harus mempunyai kompetensi dan penguasaan yang mendalam dalam bidangnya (Sum \& Taran, 2020). Guru merupakan garda terdepan dalam pendidikan khususnya dalam kegiatan proses belajar mengajar, karena guru adalah orang yang berinteraksi langsung dengan anak.

Guru adalah orang yang memegang peranan penting dalam membuat anak mengerti dan paham mengenai mata pelajaran yang diajarkan. Salah satu permasalahan pendidikan yang dihadapi oleh bangsa Indonesia adalah rendahnya mutu pendidikan pada setiap jenjang dan satuan pendidikan, khususnya pendidikan dasar dan menengah. Berbagai usaha telah dilakukan untuk meningkatkan mutu pendidikan nasional, misalnya pengembangan kurikulum nasional dan lokal, peningkatan kompetensi guru melalui pelatihan, pengadaan buku dan alat pelajaran, pengadaan dan berbaikan sarana dan prasarana pendidikan, dan meningkatkan manajemen sekolah (Ardiana, 2017). Guru merupakan elemen kunci dalam sistem pendidikan, khususnya di sekolah. Semua komponen lain, mulai dari kurikulum, sarana-prasarana, biaya, dan sebagainya tidak akan banyak berarti apabila esensi pembelajaran yaitu interaksi guru dengan peserta didik tidak berkualitas. Semua komponen lain, terutama kurikulum akan "hidup" apabila dilaksanakan oleh guru. Begitu pentingnya peran guru dalam mentransformasikan input-input pendidikan, sampai-sampai banyak pakar menyatakan bahwa di sekolah tidak akan ada perubahan atau peningkatan kualitas tanpa adanya perubahan dan peningkatan kualitas guru (Mutakin, 2015). Guru dalam proses pembelajaran memiliki peran penting terutama dalam membantu peserta didik untuk membangun sikap positif dalam belajar, membangkitkan rasa ingin tahu, mendorong kemandirian dan ketepatan logika intelektual, serta menciptakan kondisi-kondisi untuk sukses dalam belajar (Iskandar, 2013).

Guru adalah pendidik profesional dengan tugas utama mendidik, mengajar, membimbing, melatih, menilai, dan mengevaluasi peserta didik pada pendidikan anak usia dini jalur pendidikan formal, pendidikan dasar, dan pendidikan menengah hal ini termuat dalam (RI, 2015), artinya guru dalam proses pembelajaran memiliki posisi sentral dan memainkan peranan penting untuk membantu menumbuh kembangkan pengetahuan, sikap, kepribadian, dan ketrampilan peserta didik, hal ini sejalan dengan Undang-Undang Sistem Pendidikan Nasional Tahun 2003 Nomor 20, (2003) menjelaskan bahwa pendidik dalam hal ini termasuk guru adalah tenaga professional yang bertugas untuk merencanakan, melaksanakan, dan mengevaluasi hasil pembelajaran.

Peran guru menjadi salah satu komponen yang penting dan strategis melalui kinerjanya. Kinerja guru sangat penting dalam mewujudkan tujuan pendidikan nasional dan menentukan tinggi rendahnya mutu pendidikan (Susanto, 2013). Untuk melaksanakan amanat Undang-Undang Sisdiknas itu, maka pemerintah mulai meningkatkan perhatiannya terhadap kinerja guru. Oleh karena itu, guru diberikan syarat yang harus dimiliki, salah satunya adalah kompetensi yang sesuai dengan standar. Secara jelas dinyatakan dalam (RI, 2015) bahwa kompetensi adalah seperangkat pengetahuan, keterampilan, dan perilaku yang harus dimiliki, dihayati, dan dikuasai oleh guru dalam melaksanakan tugas keprofesionalan. Maksudnya guru dalam melaksanakan tugasnya harus memiliki pengetahuan yang luas dalam mengajar dan ketrampilan dalam mengelola kegiatan pembelajaran serta perilaku yang baik yang dapat menjadikan panutan bagi peserta didik. 
Pemerintah telah merumuskan empat jenis kompetensi guru secara utuh sebagai mana tercantum dalam penjelasan (Peraturan Menteri Pendidikan Dan Kebudayaan Republik Indonesia Nomor 137 tahun 2014 tentang Standar Nasional Pendidikan Anak Usia Dini, 2014) disebutkan bahwa seorang guru harus memiliki empat kompetensi yaitu kompetensi pedagogik, kompetensi kepribadian, kompetensi sosial dan kompetensi profesional. Kompetensi pedagogik merupakan kompetensi yang berkaitan dengan kemampuan yang berkenaan dengan pemahaman dan pengelolaan pembelajaran yang mendidik. Kompetensi pedagogik yang harus dikuasai guru meliputi pemahaman guru terhadap siswa, perancangan dan pelaksanaan pembelajaran, evaluasi hasil belajar, dan pengembangan siswa untuk mengaktualisasikan berbagai potensi yang dimilikinya (Suyanto \& Djihad, 2013). Kemudian guru harus memiliki kompetensi kepribadian, kompetensi kepribadian bagi guru merupakan kemampuan personal yang mencerminkan kepribadian yang mantap, stabil, dewasa, arif, berakhlak mulia, dan berwibawa, dan dapat menjadi teladan bagi siswa (Suyanto \& Djihad, 2013). Kompetensi ketiga yang harus dimiliki guru adalah Kompetensi sosial adalah kemampuan guru dalam berkomunikasi dan berinteraksi secara efektif dengan lingkungan sekolah maupun di luar lingkungan sekolah (Wibowo \& Hamrin, 2012). Kompetensi selanjutnya yang harus dimiliki seorang guru adalah kompetensi profesional, kompetensi profesional merupakan penguasaan materi pembelajaran secara luas dan mendalam yang harus dikuasai guru. Hal ini mencakup penguasaan materi mata pelajaran dan substansi keilmuan yang menaungi materi, serta penguasaaan terhadap struktur dan metodologi keilmuan (Suyanto \& Djihad, 2013).

Pendidikan anak usia dini adalah suatu upaya pembinaan yang ditunjukan kepada anak sejak lahir sampai dengan usia enam tahun yang dilakukan melalui pemberian rangsangan pendidikan untuk membantu pertumbuhan dan perkembangan jasmani dan rohani agar anak memiliki kesiapan dalam memasuki pendidikan lebih lanjut (Indonesia, 2003). Melihat fenomena tentang pentingnya masa usia dini, yang sering disebut dengan masa emas (Golden Age), maka keberadaan guru sebagai pendidik di lingkungan sekolah sangat diperlukan. Guru yang diharapkan ialah guru yang memiliki kemampuan atau kompetensi di bidangnya bukan guru yang hanya mampu mengisi kekosongan kelas. Karena guru yang berkompetensi merupakan salah satu faktor yang mempengaruhi tercapainya tujuan pembelajaran dan pendidikan di sekolah khususnya pendidikan anak usia dini (PAUD). Pada dasarnya guru memiliki potensi yang cukup tinggi untuk berkreasi dan meningkatkan kinerja, namun banyak faktor yang menghambat mereka dalam mengembangkan berbagai potensinya secara optimal. Oleh karena itu sangat dirasakan perlunya pembinaan yang kontinu dan berkesinambungan dengan program yang terarah dan sistematis terhadap para guru dan personel sekolah (Aprida, Fitria, \& Nurkhalis, 2020)

Kinerja menurut pendapat Mangkunegaran (Wardana, 2013) kinerja adalah prestasi kerja atau hasil kerja (output) baik kualitas maupun kuantitas yang dicapai SDM persatuan periode waktu dalam melaksanakan tugas kerjanya sesuai dengan tanggung jawab yang diberikan kepadanya. Menurut Srinalia kinerja dari kata dasar "kerja" yang dapat diartikan prestasi kerja, hasil kerja, atau bisa juga disebut pelaksanaan hasil kerja. Performance merupakan kata dalam bahasa Inggris. Kinerja juga merupakan sebuah hasil sebuah proses dari pelaksanaan hasil perbuatan kerja yang dikerjakan oleh manusia dalam melakukan pekerjaannya dalam kurun waktu tertentu melalui unsur-unsur tindakan yang perlihatkan dalam sebuah pretasi yang telah dicapai (Sulfemi, 2019).

Kinerja guru merupakan kemampuan seorang guru dalam melaksanakan tugas pembelajaran di madrasah dan bertanggung jawab atas peserta didik dibawah bimbingannya dengan meningkatkan prestasi belajar peserta didik (Supadi, 2019). Hal ini sejalan dengan pendapat (Gusman, 2014) yaitu kinerja guru mencerminkan kemampuan kerja guru yang terlihat dari penampilan kerja guru dalam melaksanakan tugasnya sebagai guru. Jika kemampuan kerja seorang guru bagus, maka kinerjanya juga akan semakin tinggi. Sebaliknya jika kemampuan kerja seorang guru tidak bagus, maka kinerjanya juga akan 
semakin rendah. Kinerja guru tidak hanya ditunjukkan oleh hasil kerja, tetapi juga ditunjukkan oleh perilaku dalam bekerja. Proses pembelajaran kinerja guru sangat berperan penting dalam mendukung terciptanya proses pendidikan secara efektif. Kinerja guru yang baik dapat menciptakan efektivitas dan efisiensi pembelajaran serta dapat membentuk disiplin peserta didik, madrasah, dan guru sendiri (Supadi, 2019). Kinerja guru yang tinggi salah satu- nya ditunjukkan dengan profesionalisme guru yang terdiri dari penguasaan empat kompetensi meliputi kompetensi profesional, pedagogis, kepribadian dan sosial. Untuk itu kinerja memegang peranan pen- ting dalam pencapaian tujuan pengajaran agar dapat tercapai secara maksimal (Handayani \& Rasyid, 2015). Kinerja guru merupakan elemen sinergis yang harus dikembangkan untuk menghasilkan tenaga pendidik yang profesional dan mampu melahirkan proses pendidikan yang relevan dengan tuntutan situasi, kondisi dan kebutuhan masyarakat pengguna lulusan (Purwoko, 2018). Penulis menyimpulkan bahwa kinerja adalah usaha dan kerja keras seseorang untuk mencapai tujuan. Kinerja guru adalah kemampuan seorang guru dalam menjalankan tugas yang telah diberikan kepadanya. Kinerja guru ini tidak hanya berupa hasil kerja melainkan juga ditunjukkan melalui perilaku guru dalam menjalankan tugasnya.

Faktor-faktor yang mempengaruhi kinerja guru menurut (Ondi \& Aris, 2010) ada delapan faktor yang dapat mempengaruhi kinerja guru, yaitu: kepriadian dan dedikasi, pengembangan profesi, kemampuan mengajar, komunikasi, hubungan dengan masyarakat, kedisiplinan, kesejahteraan, dan iklim kerja. Kepriadian dan dedikasi yaitu kepribadian guru akan tercermin dalam sikap dan perbuatannya dalam membina dan membimbing anak didik. Semakin baik kepribadian guru, semakin baik dedikasinya dalam menjalankan tugas dan tanggungjawabnya sebagai guru, ini berarti tercermin suatu dedikasi yang tinggi dari guru dalam melaksanakan tugas dan fungsinya sebagai pendidik. pengembangan profesi yaitu profesi guru kian hari menjadi perhatian seiring dengan perubahan ilmu pengetahuan dan teknologi yang menuntut kesiapan agar tidak ketinggalan. Profesi adalah suatu jabatan atau pekerjaan biasa seperti halnya dengan pekerjaan-pekerjaan lain. Kemampuan mengajar yaitu guru harus memiliki kemampuan merencanakan pengajaran, menuliskan tujuan pengajaran, menyajikan bahan pelajaran, memberikan pertanyaan kepada anak, mengajarkan konsep, berkomunikasi dengan anak, mengamati kelas, dan mengevaluasi hasil belajar. Kemampuan mengajar guru harus sesuai dengan tuntutan standar tugas agar memberikan efek positif bagi hasil yang ingin dicapai baik hasil akademik, sikap, keterampilan peserta didik dan perubahan pola kerja (Tutik Rachmawati dan Daryanto, 2013). Komunikasi yaitu dalam pelaksanaan tugasnya, guru perlu memperhatikan komunikasi dengan kepala sekolah, guru dengan guru, guru dengan peserta didik, dan guru dengan orangtua siswa. Kinerja guru akan meningkat seiring dengan komunikasi yang sehat antara komponen sekolah (Tutik Rachmawati dan Daryanto, 2013). Hubungan dengan masyarakat yaitu sekolah merupakan lembaga sosial yang tidak dapat dipisahkan dari masyarakat lingkungannya, sebaliknya masyarakat pun tidak dapat dipisahkan dari sekolah sebab keduanya memiliki kepentingan. Sekolah merupakan lembaga formal yang diserahi mandat untuk mendidik, melatih, dan membimbing generasi muda bagi peranannya di masa depan, sementara masyarakat merupakan pengguna jasa pendidikan itu. Hubungan sekolah dengan masyarakat adalah suatu proses komunikasi antara sekolah dengan masyarakat untuk meningkatkan pengertian masyarakat tentang kebutuhan serta kegiatan pendidikan serta mendorong minat dan kerjasama untuk masyarakat dalam peningkatan dan pengembangan sekolah (Tutik Rachmawati dan Daryanto, 2013). Kedisiplinan yaitu keadaan tertib dimana orang-orang yang tergabung dalam suatu organisasi tunduk pada peraturan-peraturan yang telah ada dengan rasa senang. Kedisiplinan sangat perlu dalam menjalankan tugas dan kewajibannya sebagai pengajar, pendidik, dan pembimbing siswa. Disiplin yang tinggi akan mampu membangun kinerja profesional sebab pemahaman disiplin yang baik guru mampu mencermati aturan-aturan dan langkah strategis dalam melaksanakan proses kegiatan belajar mengajar (Tutik Rachmawati dan Daryanto, 2013). 
Kesejahteraan, faktor kesejahteraan menjadi salah satu yang berpengaruh terhadap kinerja guru di dalam meningkatkan kualitasnya sebab semakin sejahteranya seseorang, makin tinggi kemungkinan untuk meningkatkan kerjanya. Untuk memaksimalkan kinerja guru langkah strategis yang dilakukan pemerintah yaitu memberikan kesejahteraan yang layak sesuai dengan volume kerja guru. Selain itu memberikan insentif pendukung sebagai jaminan bagi pemenuhan kebutuhan hidup guru dan keluarganya. Adanya jaminan kehidupan yang layak dapat memotivasi untuk selalu bekerja dan meningkatkan kreativitas sehingga kinerja selalu meningkat (Ondi \& Aris, 2010). Iklim kerja Sekolah merupakan suatu sistem yang terdiri dari berbagai unsur yang membentuk suatu kesatuan yang utuh. Di dalam sekolah terdapat berbagai macam sistem sosial yang berkembang dari sekelompok manusia yang saling berinteraksi menurut pola dan tujuan tertentu yang saling mempengaruhi dan dipengaruhi oleh lingkungannya sehingga membentuk perilaku dari hasil hubungan individu dengan individu maupun dengan lingkungannya. Terbentuknya iklim yang kondusif pada tempat kerja dapat menjadi faktor penunjang bagi peningkatan kinerja sebab kenyamanan dalam bekerja membuat guru berpikir dengan tenang dan terkonsentrasi hanya pada tugas yang dilaksanakannya (Tutik Rachmawati dan Daryanto, 2013).

Berdasarkan hasil wawancara dan observasi yang dilakukan peneliti di Taman Kanak-kanak di Kecamatan Weru Kabupaten Sukoharjo Jawa Tengah kepada guru, masih terdapat beberapa guru yang memiliki kualifikasi pendidikan yang belum relevan dibuktikan dengan ada beberapa guru yang belum memiliki kualifikasi S1 PAUD atau S1 Psikologi, hal ini masuk ke dalam faktor individu yaitu kurang sesuainya kualifikasi pendidikan yang dimiliki guru. (Undang-undang Sistem Pendidikan Nasional No 20 Tahun 2003, 2003) tentang Sistem Pendidikan Nasional menyatakan bahwa guru adalah tenaga pendidik profesional. Guru dipersyaratkan memiliki kualifikasi akademik minimal Sarjana Strata Satu (S1) yang relevan dan menguasai kompetensi sebagai agen pembelajaran, hal tersebut juga tertuang dalam (RI, 2015), disebutkan bahwa Guru wajib memiliki kualifikasi akademik, kompetensi, sertifikat pendidik, sehat jasmani dan rohani, serta memiliki kemampuan untuk mewujudkan tujuan pendidikan nasional.

Berdasarkan hasil wawancara yang dilakukan peneliti di Taman Kanak-kanak di Kecamatan Weru Kabupaten Sukoharjo Jawa Tengah kepada guru, masih terdapat guru yang memiliki motivasi yang rendah, kesenjangan gaji antara guru satu dengan yang lainnya, kurangnya interaksi antara guru dengan siswa, dan kurangnya interaksi guru dengan orangtua/masyarakat. Motivasi kerja guru merupakan faktor penting dalam peningkatan kinerja guru karena sebagai pendorong utama setiap guru melaksanakan tugas profesinya sesuai ketentuan yang berlaku. Menjadi guru tanpa motivasi kerja akan cepat merasa jenuh karena tidak adanya unsur pendorong (Pramesti \& Muhyadi, 2018). Pendapat Mulyasa (Ardiana, 2017) "Para pegawai (guru) akan bekerja dengan sungguh-sungguh apabila memiliki motivasi yang tinggi. Apabila memiliki motivasi yang positif, ia akan memperlihatkan minat, mempunyai perhatian, dan ingin ikut serta dalam suatu tugas atau kegiatan". Sesuai dengan pendapat tersebut, guru yang masih kurang berhasil dalam mengajar dikarenakan mereka kurang termotivasi untuk mengajar sehingga berdampak terhadap menurunnya produktivitas atau kinerja guru. Untuk itu diperlukan peran kepala sekolah untuk memotivasi para guru untuk meningkatkan kinerjanya. Guru yang memiliki motivasi tinggi akan memandang berbagai kekurangan yang ada di sekolah sebagai tantangan. Ia akan berusaha sedapat mungkin untuk mengatasi kekurangan itu. Dengan adanya perhatian yang baik terhadap guru, akan dapat menimbulkan motivasi para guru untuk berbuat yang terbaik dalam melakukan tugas sehingga menumbuhkan komitmen dalam melakukan pekerjaan yang berkualitas dan bertanggung jawab demi kemajuan organisasi (Dewi, 2015).

Berdasarkan hasil wawancara yang dilakukan peneliti di Taman Kanak-kanak di Kecamatan Weru Kabupaten Sukoharjo Jawa Tengah kepada guru, Faktor lain yang juga 
mempunyai peran dalam upaya meningkatkan kinerja adalah budaya kerja/organisasi. Budaya kerja dapat dilihat dengan rendahnya tingkat penghargaan terhadap kinerja karyawan, rendahnya tingkat kesejahteraan, komunikasi dan interaksi antara karyawan, wali murid/orang tua, pimpinan dan lingkungan masyarakat masih ada jarak atau pembatas, sehingga terlihat kurang harmonis. Budaya sekolah atau iklim kerja menggambarkan suasana dan hubungan kerja antara sesama guru, guru dengan kepala sekolah, guru dengan tenaga kependidikan lainnya, dan Dinas di lingkungannya. Hal ini merupakan wujud dari lingkungan kerja yang kondusif. Suasana seperti ini sangat dibutuhkan guru dan kepala sekolah untuk melaksanakan pekerjaannya dengan lebih efektif (Setiyati, 2014).

Dari gambaran kondisi yang ada setelah peneliti melakukan wawancara kepada guru di lapangan ternyata kinerja guru belum maksimal dibuktikan dalam melaksanakan kegiatan guru tidak memakai RPPH sebagai acuan pelaksanaan kegiatan, RPPH disusun seusai kegiatan berlangsung, dalam kurun waktu satu semester, dan disusun terkait dengan kepentingan akreditasi, kemudian masih ada beberapa guru yang belum memiliki kualifikasi yang sesuai dengan standar yang dikeluarkan oleh pemerintah, seperti disebutkan diatas bahwa kualifikasi guru seharusnya S1 PAUD/Psikologi namun masih ada beberapa guru yang kualifikasinya belum sesuai, selanjutnya pelaksanaan kegiatan inti didominasi dengan pemberian tugas untuk mengerjakan majalah anak sehingga anak lebih pasif dalam pelaksanaaan kegiatan, anak yang bosan memilih untuk melaksanakan kegiatan lain, sehingga tidak memperhatikan guru, motivasi guru rendah, kesenjangan gaji guru, dalam melaksanaan kegiatan guru kurang interaksi dengan siswa, dalam melaksanakan kegiatan guru kurang interaksi dengan orangtua siswa, dan masih banyaknya guru yang tidak bisa mengoperasikan teknologi komputer. Dari latar belakang diatas maka peneliti ingin meneliti tentang faktor-faktor apa saja yang berpengaruh terhadap kinerja guru di Taman Kanak-kanak se-Kecamatan Weru Kabupaten Sukoharjo Jawa Tengah.

\section{METODOLOGI}

Penelitian yang digunakan peneliti adalah metode kuantitatif, teknik analisis data pada penelitian ini menggunakan uji analisis faktor CFA. Penelitian menggunakan desain penelitian kuantitatif dipilih peneliti karena untuk menjaring data dalam bentuk data numerik dengan menggunakan instrument yang divalidasi yang mencerminkan dimensi dan indikator dari variable dan disebarkan kepada populasi atau sampel tertentu. Penelitian kuantitatif menghasilkan data dan informasi yang lebih akurat dan objektif karena dijaring dengan menggunakan metode standar dan menggunakan analisis statistik dan dapat direplikasi. Uji analisis faktor CFA dipilih karena analisis faktor digunakan untuk mereduksi data dan menginterpretasikannya sebagai suatu variabel baru yang berupa variabel bentukan. Analisis faktor juga digunakan untuk mengetahui faktor-faktor dominan dalam menjelaskan suatu masalah. Adapun alur langkah kegiatan penelitian dapat dilihat pada gambar 1.

Populasi dalam penelitian ini adalah semua guru di Taman Kanak-kanak seKecamatan Weru Kabupaten Sukoharjo. Adapun jumlah guru pada masing-masing sekolah yang dijadikan anggota populasi dijelaskan pada tabel 1.

Penelitian ini menggunakan sampel jenuh yaitu teknik penentuan sampel yang menggunakan semua anggota populasi sebagai sampel. Alasan menggunakan sampel jenuh agar dapat menggambarkan keadaan lebih akurat dengan kesalahan yang sangat kecil. Penelitian ini menggunakan sampel jenuh yaitu keseluruhan anggota populasi dijadikan sebagai sampel dengan jumlah 59 guru se-Kecamatan Weru Kabupaten Sukoharjo Jawa Tengah yang tersebar di 21 lembaga Taman Kanak-kanak se-Kecamatan Weru Kabupaten Sukoharjo. Waktu Penelitian dilaksanakan pada bulan September 2020- Oktober 2020. 


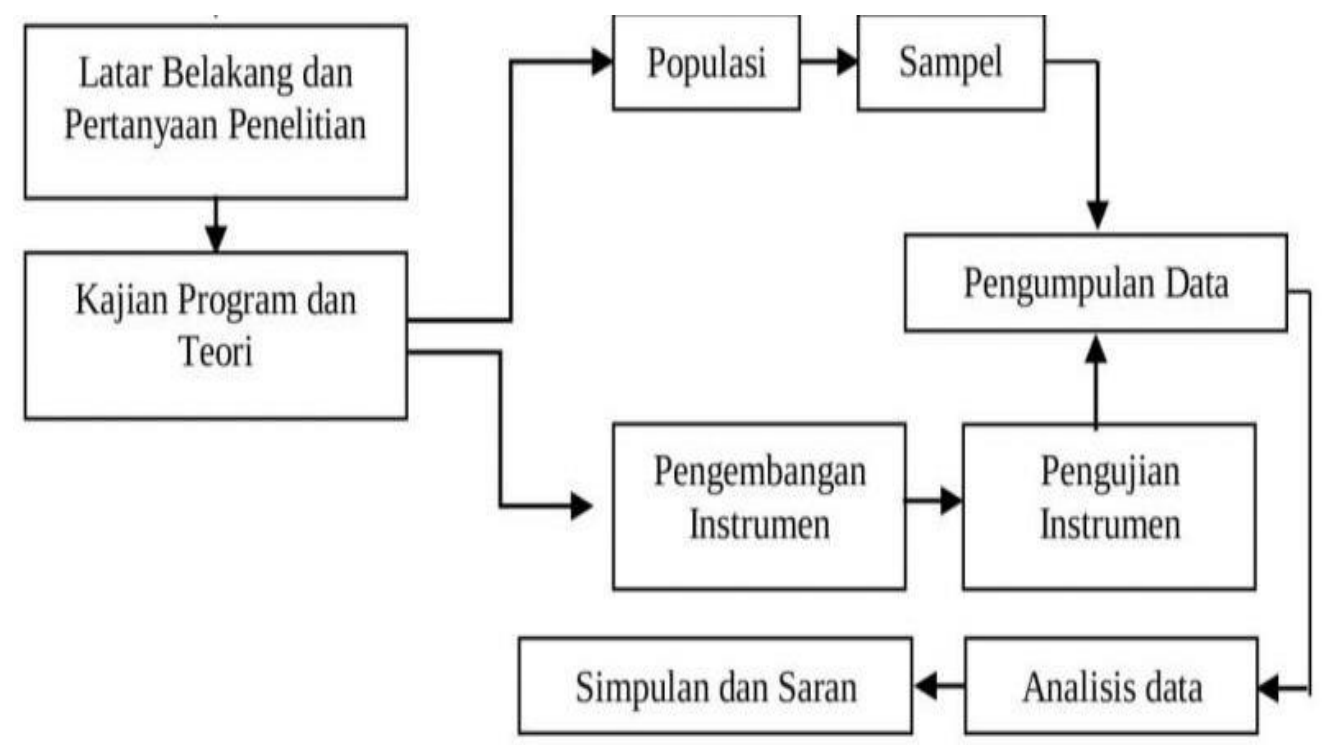

Gambar 1. Langkah kegiatan penelitian

Tabel 1. Daftar Nama Taman Kanak-kanak dan Jumlah Guru

\begin{tabular}{clcc}
\hline No. & \multicolumn{1}{c}{ Nama TK } & Guru DPK & Guru WB/ Bantu \\
\hline 1 & TK Desa Weru & 1 & 1 \\
2 & TK Desa Tawang 02 & 1 & 2 \\
3 & TK Desa Ngreco 01 & 2 & - \\
4 & TK Desa Ngreco 02 & 1 & 1 \\
5 & TK Desa Ngreco 04 & 1 & 1 \\
6 & TK Desa Ngreco 05 & 1 & 2 \\
7 & TK Desa Karangmojo 01 & 1 & 1 \\
8 & Yayasan PAUD Ds. Karangmojo & 2 & 1 \\
9 & TK Desa Alasombo 02 & 1 & 1 \\
10 & TK Desa Karanganyar 01 & 2 & 2 \\
11 & TK Desa Jatingarang 01 & 2 & 1 \\
12 & TK Desa Krajan 01 & 2 & 2 \\
13 & TK Desa Karangwuni 01 & 1 & 1 \\
14 & TK Desa Karangwuni 03 & 2 & 3 \\
15 & TK Desa Karangtengah & 2 & 3 \\
16 & TK Desa Grogol 01 & 2 & - \\
17 & TK Desa Grogol 02 & 2 & 1 \\
18 & TK Desa Karakan 01 & 1 & 1 \\
19 & TK Desa Tegalsari 02 & 1 & 1 \\
20 & TK Desa Tegalsari 03 & 2 & 1 \\
21 & TK PGRI Tegalsari & 1 & 2 \\
\hline \multicolumn{5}{c}{ Sumber dari UPTD Pendidikan Kecamatan Weru Kabupaten Sukoharjo Maret 2020 }
\end{tabular}

Teknik mengumpulkan data dalam penelitian ini yaitu angket, dengan partisipan semua sampel yaitu 59 guru, penulis berasumsi agar dapat menggambarkan keadaan lebih akurat dengan kesalahan yang sangat kecil. Angket yang digunakan dalam penelitian ini menggunakan instrumen berskala gurtman dan menggunakan 3 variabel (6 faktor) guna menganalisa kinerja guru, yaitu faktor individu (pedadgogik, kepribadian, profesional, sosial) yang terdiri dari 41 item pertanyaan, faktor psikologis (motivasi) yang terdiri dari 21 pertanyaan dan faktor organisasi (disiplin) yang terdiri dari 9 item pertanyaan. Kisi- kisi instrument penelitian dijelaskan pada tabel 2. 
Tabel 2. Kisi-Kisi Instrumen Penilaian

\begin{tabular}{lllll}
\hline Variabel & \multicolumn{1}{c}{ Deskripsi } & Nomor item & Jumlah Butir \\
\hline & a. & Kompetensi pedagogik & $1-14$ & 14 \\
\cline { 2 - 4 } Faktor Individu & b. & $\begin{array}{l}\text { Kompetensi } \\
\text { kepribadian }\end{array}$ & $15-20$ & 6 \\
\cline { 2 - 4 } & c. & $\begin{array}{l}\text { Kompetensi } \\
\text { profesional }\end{array}$ & $21-30$ & 10 \\
\cline { 2 - 4 } & d. & Kompetensi sosial & $31-41$ & 11 \\
\hline $\begin{array}{l}\text { Faktor } \\
\text { Psikologis }\end{array}$ & e. & Motivasi guru & $42-62$ & 21 \\
\hline $\begin{array}{l}\text { Faktor } \\
\text { Organisasi }\end{array}$ & f. & Kedisiplinan guru & $63-71$ & 9 \\
\hline Jumlah & & & & 71 \\
\hline
\end{tabular}

\section{HASIL DAN PEMBAHASAN}

Pengujian dalam penelitian ini menggunakan analisis faktor atau disebut CFA (Confirmatory Factor Analysis). Secara umum analisis faktor ialah suatu teknik analisa yang memuat informasi tentang pengelompokan variabel faktor dalam suatu penelitian. Analisis faktor bertujuan untuk menyaring variabel mana yang paling unggul atau paling dominan dari beberapa variabel yang dipilih oleh peneliti. Hasil analisis faktor dapat juga digunakan untuk membedakan komponen atau variabel prioritas berdasarkan perankingan yang ada. Hasil analisis faktor dijelaskan pada tabel 3.

Tabel 3. Total Variance Explained

\begin{tabular}{|c|c|c|c|c|c|c|c|c|c|}
\hline \multirow[b]{2}{*}{$\begin{array}{l}\text { Compo } \\
\text { nent }\end{array}$} & \multicolumn{3}{|c|}{$\begin{array}{l}\text { Initial Eigenvalues } \\
\% \% \text { of }\end{array}$} & \multicolumn{3}{|c|}{$\begin{array}{l}\text { Extraction Sums of } \\
\text { Squared Loadings } \\
\quad \% \text { of }\end{array}$} & \multicolumn{3}{|c|}{$\begin{array}{l}\text { Rotation Sums of } \\
\text { Squared Loadings }\end{array}$} \\
\hline & Total & $\begin{array}{c}\text { Varianc } \\
\text { e }\end{array}$ & $\begin{array}{l}\text { Cumulati } \\
\text { ve } \%\end{array}$ & Total & $\begin{array}{l}\text { Varian } \\
\text { ce }\end{array}$ & $\begin{array}{l}\text { Cumulat } \\
\text { ive } \%\end{array}$ & Total & $\begin{array}{c}\% \text { of } \\
\text { Variance }\end{array}$ & $\begin{array}{l}\text { Cumul } \\
\text { ative } \%\end{array}$ \\
\hline 1 & 2,506 & 41,761 & 41,761 & 2,506 & 41,761 & 41,761 & 2,481 & 41,349 & 41,349 \\
\hline 2 & 1,462 & 24,359 & 66,120 & 1,462 & 24,359 & 66,120 & 1,448 & 24,138 & 65,488 \\
\hline 3 & 1,005 & 16,745 & 82,865 & 1,005 & 16,745 & 82,865 & 1,043 & 17,378 & 82,865 \\
\hline 4 & ,538 & 8,966 & 91,832 & & & & & & \\
\hline 5 & 293 & 4,879 & 96,711 & & & & & & \\
\hline 6 & 197 & 3,289 & 100,000 & & & & & & \\
\hline
\end{tabular}

Extraction Method: Principal Component Analysis.

Tabel 3 menunjukkan nilai masing-masing variabel yang dianalisis. Dalam penelitian ini terdapat 6 faktor berarti terdapat 6 komponen yang dianalisis. Terdapat dua cara untuk menjelaskan suatu varian, yaitu Intial Eigenvalues dan Extraction Sums of Squared Loadings. Pada varian Intial Eigenvalues menunjukkan faktor yang terbentuk. Apabila semua faktor dijumlahkan menunjukkan jumlah faktor (yaitu 2,506 + 1,462 + 1,005 + 0,538 + 0,293 + 0,197= 6 faktor). Sedangkan pada bagian Extraction Sums of Squared Loadings menunjukkan jumlah variasi atau banyaknya faktor yang dapa dibentuk, pada hasil output di atas terdapat tiga variasi faktor yaitu:

Faktor 1 menghasilkan nilai Eigenvalues sebesar 2,506 atau > 1 maka faktor 1 mampu menjelaskan 41,761\% varian kinerja guru. Faktor 2 menghasilkan nilai Eigenvalues sebesar 1,462 atau > 1 maka faktor 2 mampu menjelaskan 24,359\% varian kinerja guru. Faktor 3 menghasilkan nilai Eigenvalues sebesar 1,005 atau > 1 maka faktor 3 mampu menjelaskan $16,745 \%$ varian kinerja guru. 
Nilai total Eigenvalues untuk komponen 4, 5, 6 tidak dihitung sebab nilai Eigenvalues di bawah 1 maka tidak menjadi faktor. Selanjutnya adalah menentukan banyak varians dari diagram Scree Plot. Hasil analisis faktor dijelaskan pada gambar 2.

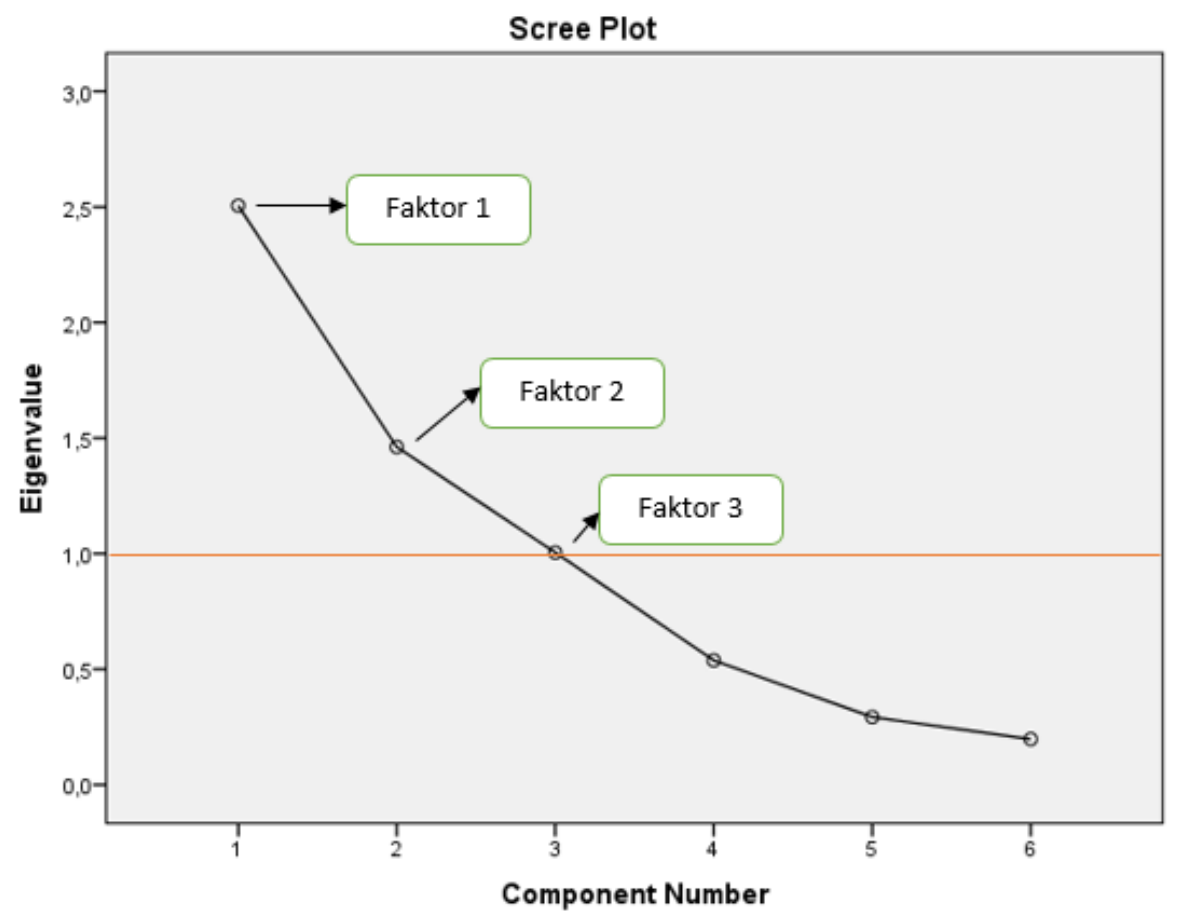

Gambar 2. Scree Plot

Berdasarkan diagram gambar 2, terdapat 3 titik komponen yang memiliki nilai Eigenvalues $>1$ maka dapat diartikan bahwa terdapat 3 faktor yang dapat terbentuk. Selain dari bentuk diagram, faktor yang terbentuk juga dapat dilihat dari tabel 4 Rotated Component Matrix.

Tabel 4. Rotated Component Matrix ${ }^{a}$

\begin{tabular}{lccc}
\hline & \multicolumn{3}{c}{ Component } \\
& 1 & 2 & \multicolumn{1}{c}{3} \\
\hline FI_PEDAGOGIK &, 930 &,- 021 &, 052 \\
FI_KEPRIBADIAN &, 896 &,- 012 &,- 085 \\
FI_PROFESIONAL &, 895 &, 144 &, 055 \\
FI_SOSIAL &, 836 &,- 031 &,- 223 \\
FP_MOTIVASI &, 102 &, 852 &, 132 \\
FO_DISIPLIN &, 004 &,- 055 &, 981 \\
\hline
\end{tabular}

Extraction Method: Principal Component Analysis. Rotation Method: Varimax with Kaiser Normalization. Rotation converged in 4 iterations.

Untuk memastikan suatu variabel masuk dalam kelompok yang mana, maka dapat ditentukan dengan melihat nilai korelasi terbesar antara variabel dengan faktor yang terbentuk. Hasil analisis faktor model rotasi seperti tabel di atas adalah terdapat 3 bentuk variabel/ faktor, berikut ini penjelasannya.

Faktor 1 ditempati oleh Faktor Individu yang terdiri dari pedagogik, kepribadian, profesional dan sosial. Karena nilai korelasi terbesar 4 faktor ini terdapat di faktor 1 . Faktor 2 ditempati oleh Faktor Psikologi (Motivasi). Karena nilai korelasi terbesar faktor ini terdapat di faktor 2. Faktor 3 ditempati oleh Faktor Organisasi (Disiplin). Karena nilai korelasi faktor ini terdapat di faktor 3. 
Berikutnya adalah mendeskripsikan faktor berdasarkan tabel 5 Component Transformation Matrix.

Tabel 4. Component Transformation Matrix

\begin{tabular}{lccr}
\hline Component & \multicolumn{4}{c}{2} & 3 & \\
\hline 1 &, 989 &, 147 &, 019 \\
2 &,- 136 &, 949 &,- 286 \\
3 &,- 060 &, 280 &, 958 \\
\hline Extraction Method: Principal Component Analysis. \\
\multicolumn{4}{l}{ Rotation Method: Varimax with Kaiser Normalization. }
\end{tabular}

Berdasarkan tabel Component Transformation Matrix di atas, menunjukkan bahwa pada komponen faktor 1 nilai korelasinya sebesar 0,989>0,50; komponen faktor 2 nilai korelasinya sebesar 0,949>0,50 dan komponen faktor 3 nilai korelasinya sebesar 0,958>0,50 maka dapat disimpulkan bahwa ketiga faktor yang terbentuk yaitu Faktor Individu, Faktor Psikologis dan Faktor Organisasi dapat dikatakan layak untuk merangkum variabel kinerja guru Taman Kanak-kanak di Kecamaan Weru, Kabupaten Sukoharjo.

\section{Pembahasan}

Penelitian ini dilakukan untuk mengetahui faktor-faktor apa saja yang mempengaruhi kinerja guru di Taman Kanak-kanan se-Kecamatan Weru, Kabupaten Sukoharjo. Berdasarkan hasil penelitian yang telah dilakukan, maka pembahasan masing-masing faktor disajikan sebagai berikut.

\section{Pengaruh Faktor Individu Terhadap Kinerja Guru}

Hasil penelitian menunjukkan bahwa faktor individu (kompetensi guru) yang terdiri dari kompetensi pedagogik, kompetensi kepribadian, kompetensi profesional dan kompetensi sosial berpengaruh terhadap kinerja guru. Hal ini dibuktikan dengan nilai Eigenvalues sebesar 2,506 atau > 1 maka faktor 1 mampu menjelaskan 41,761\% varian kinerja guru. Hal ini sesuai dengan pendapat (Tutik Rachmawati dan Daryanto, 2013) faktor-faktor yang mempengaruhi kinerja guru salah satunya yaitu faktor kemampuan karena seorang guru harus memiliki kompetensi dan kemampuan merencanakan pengajaran, menuliskan tujuan pengajaran, menyajikan bahan pelajaran, memberikan pertanyaan kepada anak, mengajarkan konsep, berkomunikasi dengan anak, mengamati kelas, dan mengevaluasi hasil belajar. Kemampuan mengajar guru harus sesuai dengan tuntutan standar kompetensi yang harus dimiliki guru yaitu guru harus memiliki kompetensi pedagogik, kompetensi kepribadian, kompetensi profesional dan kompetensi sosial yang sesuai agar memberikan efek positif bagi hasil yang ingin dicapai baik hasil akademik, sikap, keterampilan peserta didik dan perubahan pola kerja. Hal ini juga sejalan dengan pemerintah telah merumuskan empat jenis kompetensi guru secara utuh sebagai mana tercantum dalam penjelasan Standar Nasional Pendidikan Anak Usia Dini (2014) disebutkan bahwa seorang guru harus memiliki empat kompetensi yaitu kompetensi pedagogik, kompetensi kepribadian, kompetensi sosial dan kompetensi profesional. Kompetensi pedagogik merupakan kompetensi yang berkaitan dengan kemampuan yang berkenaan dengan pemahaman dan pengelolaan pembelajaran yang mendidik. Kompetensi pedagogik yang harus dikuasai guru meliputi pemahaman guru terhadap siswa, perancangan dan pelaksanaan pembelajaran, evaluasi hasil belajar, dan pengembangan siswa untuk mengaktualisasikan berbagai potensi yang dimilikinya (Suyanto \& Djihad, 2013). Kemudian guru harus memiliki kompetensi kepribadian, kompetensi kepribadian bagi guru merupakan kemampuan personal yang mencerminkan kepribadian yang mantap, stabil, dewasa, arif, berakhlak mulia, dan berwibawa, dan dapat menjadi teladan bagi siswa (Suyanto \& Djihad, 2013). Kompetensi ketiga yang harus dimiliki guru adalah Kompetensi sosial adalah kemampuan guru dalam berkomunikasi dan berinteraksi 
secara efektif dengan lingkungan sekolah maupun di luar lingkungan sekolah (Wibowo \& Hamrin, 2012). Kompetensi selanjutnya yang harus dimiliki seorang guru adalah kompetensi profesional, kompetensi profesional merupakan penguasaan materi pembelajaran secara luas dan mendalam yang harus dikuasai guru. Hal ini mencakup penguasaan materi mata pelajaran dan substansi keilmuan yang menaungi materi, serta penguasaan terhadap struktur dan metodologi keilmuan (Suyanto \& Djihad, 2013). Kemudian kinerja guru yang tinggi salah satunya ditunjukkan dengan profesionalisme guru yang terdiri dari penguasaan empat kompetensi meliputi kompetensi profesional, pedagogis, kepribadian dan sosial. Untuk itu kinerja memegang peranan pen- ting dalam pencapaian tujuan pengajaran agar dapat tercapai secara maksimal (Handayani \& Rasyid, 2015).

\section{Pengaruh Faktor Psikologis terhadap Kinerja Guru}

Hasil penelitian menunjukkan bahwa faktor psikologis yaitu motivasi guru berpengaruh terhadap kinerja guru. Hal ini dibuktikan dengan nilai Eigenvalues sebesar 1,462 atau $>1$ maka faktor 2 mampu menjelaskan 24,359\% varian kinerja guru. Hal ini sesuai dengan pendapat (Ondi \& Aris, 2010) faktor-faktor yang mempengaruhi kinerja guru salah satunya yaitu faktor kesejahteraan atau motivasi guru, faktor kesejahteraan menjadi salah satu yang berpengaruh terhadap kinerja guru di dalam meningkatkan kualitasnya sebab semakin sejahteranya seseorang, makin tinggi kemungkinan untuk meningkatkan kerjanya. Untuk memaksimalkan kinerja guru langkah strategis yang dilakukan pemerintah yaitu memberikan kesejahteraan yang layak sesuai dengan volume kerja guru. Selain itu memberikan insentif pendukung sebagai jaminan bagi pemenuhan kebutuhan hidup guru dan keluarganya. Adanya jaminan kehidupan yang layak dapat memotivasi untuk selalu bekerja dan meningkatkan kreativitas sehingga kinerja selalu meningkat. Motivasi kerja guru merupakan faktor penting dalam peningkatan kinerja guru karena sebagai pendorong utama setiap guru melaksanakan tugas profesinya sesuai ketentuan yang berlaku. Menjadi guru tanpa motivasi kerja akan cepat merasa jenuh karena tidak adanya unsur pendorong (Pramesti \& Muhyadi, 2018). Pendapat Mulyasa dalam Ardiana (2017) “Para pegawai (guru) akan bekerja dengan sungguh-sungguh apabila memiliki motivasi yang tinggi. Apabila memiliki motivasi yang positif, ia akan memperlihatkan minat, mempunyai perhatian, dan ingin ikut serta dalam suatu tugas atau kegiatan".

\section{Pengaruh Faktor Organisasi terhadap Kinerja Guru}

Hasil penelitian menunjukkan bahwa faktor organisasi yaitu disiplin guru berpengaruh terhadap kinerja guru. Hal ini dibuktikan dengan nilai Eigenvalues sebesar 1,005 atau > 1 maka faktor 2 mampu menjelaskan 16,745\% varian kinerja guru. Hal ini sesuai dengan pendapat Tutik Rachmawati dan Daryanto (2013) faktor-faktor yang mempengaruhi kinerja guru salah satunya yaitu kedisiplinan. Disiplin yaitu keadaan tertib dimana orang-orang yang tergabung dalam suatu organisasi tunduk pada peraturan-peraturan yang telah ada dengan rasa senang. Kedisiplinan sangat perlu dalam menjalankan tugas dan kewajibannya sebagai pengajar, pendidik, dan pembimbing siswa. Disiplin yang tinggi akan mampu membangun kinerja profesional sebab pemahaman disiplin yang baik guru mampu mencermati aturanaturan dan langkah strategis dalam melaksanakan proses kegiatan belajar mengajar. Faktor budaya kerja/ organisasi dapat dilihat dengan rendahnya tingkat penghargaan terhadap kinerja karyawan, rendahnya tingkat kesejahteraan, komunikasi dan interaksi antara karyawan, wali murid/orang tua, pimpinan dan lingkungan masyarakat masih ada jarak atau pembatas, sehingga terlihat kurang harmonis. Budaya sekolah atau iklim kerja menggambarkan suasana dan hubungan kerja antara sesama guru, guru dengan kepala sekolah, guru dengan tenaga kependidikan lainnya, dan Dinas di lingkungannya. Hal ini merupakan wujud dari lingkungan kerja yang kondusif. Suasana seperti ini sangat dibutuhkan guru dan kepala sekolah untuk melaksanakan pekerjaannya dengan lebih efektif (Setiyati, 2014). 


\section{SIMPULAN}

Hasil penelitian menunjukkan bahwa faktor individu (kompetensi guru) yang terdiri dari kompetensi pedagogik, kompetensi kepribadian, kompetensi profesional dan kompetensi sosial berpengaruh terhadap kinerja guru, hal ini dibuktikan dengan nilai Eigenvalues sebesar 2,506. Hasil penelitian menunjukkan bahwa faktor psikologis yaitu motivasi guru berpengaruh terhadap kinerja guru, hal ini dibuktikan dengan nilai Eigenvalues sebesar 1,462. Hasil penelitian menunjukkan bahwa faktor organisasi yaitu disiplin guru berpengaruh terhadap kinerja guru.

\section{UCAPAN TERIMA KASIH}

Dengan selesainya penelitian ini penulis mengucapkan terimakasih kepada dinas pendidikan dan kebudayaan kecamatan weru, kepala sekolah dan guru TK di Kecamatan Weru Kabupaten Sukoharjo yang telah membantu penulis untuk mendapatkan informasi guna menyelesaikan penelitian yang dilakukan sehingga penelitian ini dapat terlaksana dengan baik, lancar, dan sukses.

\section{DAFTAR PUSTAKA}

Ardiana, T. E. (2017). Pengaruh Motivasi Kerja Guru Terhadap Kinerja Guru Akuntansi Smk Di Kota Madiun. Jurnal Akuntansi Dan Pajak, 17(02), 14-23. https:// doi.org/10.29040/jap.v17i02.11

Asmarazisa, D. (2018). Pengaruh Supervisi Kepala Sekolah Dan Motivasi Kerja Terhadap Kinerja Guru Smk N 2 Batam. Jurnal Bening, 5(1), 78. https:// doi.org/10.33373/bening.v5i1.1346

Dewi, T. anggia. (2015). Pengaruh profesionalisme guru dan motivasi kerja terhadap kinerja guru ekonomi SMA se-Kota Malang. PROMOSI (Jurnal Pendidikan Ekonomi), 3(1), 2435. https:/ / doi.org/10.24127/ja.v3i1.148

Gusman, H. E. (2014). Hubungan gaya kepemimpinan kepala sekolah dengan kinerja guru di smp n kecamatan palembayan kabupaten agam. Jurnal Bahana Manajemen Pendidikan, 2, 293-301. https:// doi.org/10.24036/bmp.v2i1.3764

Handayani, T., \& Rasyid, A. A. (2015). Pengaruh Kepemimpinan Kepala Sekolah, Motivasi Guru, Dan Budaya Organisasi Terhadap Kinerja Guru Sma Negeri Wonosobo. Jurnal Akuntabilitas Manajemen Pendidikan, 3(2), 264-277. https:// doi.org/10.21831/amp.v3i2.6342

Indonesia, R. (2003). Undang Undang Nomor 20 Tahun 2003 tentang Sistem Pendidikan Nasional. Iskandar, U. (2013). Kepemimpinan Kepala Sekolah Dalam Peningkatan Kinerja Guru. Jurnal Visi Ilmu Pendidikan, 10(1), 1018-1027. https://doi.org/http://dx.doi.org/10.26418/jvip.v10i1.2061

Peraturan Menteri Pendidikan Dan Kebudayaan Republik Indonesia Nomor 137 tahun 2014 tentang Standar Nasional Pendidikan Anak Usia Dini, 13 (2014) (testimony of Republik Indonesia Kemendikbud).

Undang-undang Sistem Pendidikan Nasional No 20 Tahun 2003, Kemendikbud (2003).

Mutakin, T. Z. (2015). Pengaruh Kompetensi, Kompensasi, dan Latar Belakang terhadap Kinerja Guru. Formatif: Jurnal Ilmiah Pendidikan MIPA, 3(2), 145-156. https:/ / doi.org/10.30998/formatif.v3i2.122

Ondi \& Aris. (2010). Etika Profesi Keguruan. PT. Refika Aditama.

Standar Nasional Pendidikan Anak Usia Dini, Pub. L. No. 137 Tahun 2014 (2014).

Pramesti, D., \& Muhyadi, M. (2018). Faktor-faktor yang mempengaruhi kinerja guru SMA. Harmoni Sosial: Jurnal Pendidikan IPS, 5(1), 43-56. https:// doi.org/10.21831/hsjpi.v5i1.11854

Purwoko, S. (2018). Pengaruh kepemimpinan kepala sekolah, komitmen guru, disiplin kerja guru, dan budaya sekolah terhadap kinerja guru SMK. Jurnal Akuntabilitas Manajemen Pendidikan, 6(2), 150. https://doi.org/10.21831/amp.v6i2.8467 
RI. (2015). Undang-undang Republik Indonesia nomor 14 tahun 2005 tentang Guru dan Dosen, pasal 1 ayat 1 (hal. pasal 1 ayat 1 ).

Sri Setiyati. (2014). Pengaruh Kepemimpinan Kepala Sekolah, Motivasi Kerja, dan Budaya Sekolah Terhadap Kinerja Guru. Jurnal Pendidikan Teknologi dan Kejuruan, 22(2), 200206. https:// doi.org/10.21831/jptk.v22i2.8931

Sulfemi, W. B. (2020). Pengaruh Rasa Percaya Diri dan Gaya Kepemimpinan Kepala Sekolah terhadap Kinerja Guru di Kecamatan Ciampea Kabupaten Bogor. Nidomul Haq: Jurnal Manjemen Pendidikan Islam, 5, 157-179. https://doi.org/https://doi.org/10.31538/ndh.v5i2.557

Sum, T. A., \& Taran, E. G. M. (2020). Kompetensi Pedagogik Guru PAUD dalam Perencanaan dan Pelaksanaan Pembelajaran. Jurnal Obsesi : Jurnal Pendidikan Anak Usia Dini, 4(2), 543. https:// doi.org/10.31004/obsesi.v4i2.287

Supadi. (2019). Kinerja Guru. In Ijrm (Vol. 2, Nomor 2, hal. 22). Raja Grafindo Persada.

Supriyono, A. (2017). the Influence of Pedagogic, Professional Competency, and Work Motivation Onteacher Performance of Elementary School. Jurnal Pendidikan, 18(2), 112. https:// doi.org/https:// doi.org/10.33830/jp.v18i2.269.2017

Susanto, H. (2013). Faktor-Faktor yang Mempengaruhi Kinerja Guru Sekolah Menengah Kejuruan. Jurnal Pendidikan Vokasi, 2(2), 197-212. https:// doi.org/10.21831/jpv.v2i2.1028

Suyanto \& Djihad. (2013). Calon Guru dan Guru Profesional. Multi Pressindo.

Tutik Rachmawati dan Daryanto. (2013). Penilaian Kinerja Guru dan Angka Kreditnya. In Gava Media. Gava Media.

Wardana, D. S. (2013). Motivasi berprestasi dengan kinerja guru yang sudah disertifikasi. Jurnal Ilmiah Psikologi Terapan. Jurnal Ilmiah Psikologi Terapan, 01(01), 98-109. https://doi.org/10.22219/jipt.v1i1.1361

Wibowo, A., \& Hamrin. (2012). Menjadi Guru Berkarakter: Strategi Membangun Kompetensi dan Karakter Guru. Pustaka Pelajar. 